$B J M G 10 / 2(2007) 43-54$

$10.2478 / \mathrm{v} 10034-008-0006-0$

ORIGINAL ARTICLE

\title{
LINKAGE ANALYSIS BY A TRANSMISSION/ DISEQUILIBRIUM TEST OF RUSSIAN SIBLING PAIRS WITH CORONARY ARTERY DISEASE
}

\author{
Tupitsina $\mathrm{TV}^{1}, *$, Slominsky PA ${ }^{1}$, Yufereva $\mathrm{YM}^{2}$, \\ Perova $\mathrm{NI}^{2}$, Aronov $\mathrm{DM}^{2}$, Limborska $\mathrm{SA}^{1}$
}

\begin{abstract}
*Corresponding Author: Dr. Tatiana V. Tupitsina, Department of Human Molecular Genetics, Institute of Molecular Genetics of Russian Academy of Sciences, Kurchatov sq. 2, 123182, Moscow, Russia; Tel.: +007-499-1960210; Fax:+007-499-1960221; E-mail: tanya_tupitsina@mail.ru
\end{abstract}

\section{ABSTRACT}

We studied the association between coronary artery disease (CAD) and polymorphisms of the $A B C A 1, A C E, A G T$, eNOS and EFNB3 genes in 85 Russian patients with angiography-proven CAD and 100 of their siblings. No gene analyzed had a z-score value of more than 2.47 for CAD or for its main clinical presentations due to sibling transmission/ disequilibrium test (S-TDT). However, the DD genotype of $A C E$ is significantly more prevalent in siblings with $\mathrm{CAD}[p=0.025$, relative risk $(R R)$ $2.8]$, angina $(p=0.028, R R=3.3)$ and myocardial infarction (MI) $(p=0.018, R R=5.5)$. An increased risk of $\mathrm{CAD}$, and its main manifestations, was associated with the R1587 allele of the $A B C A 1$ gene: the $R R$ for developing CAD was 4.88 , for MI 6.18 , and for angina 3.69 for siblings who were carriers of the R1587R and R1587K genotypes. Index of stenosis was significantly higher in probands with the $\mathrm{K} 219 \mathrm{~K}$ and $\mathrm{R} 219 \mathrm{~K}$ genotypes $(p=0.001)$. The combination of genotype K219K with R219K was more frequent among siblings with CAD $(p=0.044$, $R R=2.38)$, arterial hypertension $(p=0.023, R R=$ $2.87)$ and angina $(p=0.027, R R=3.3)$. Thus, none

\footnotetext{
${ }^{1}$ Institute of Molecular Genetics of Russian Academy of Sciences, Moscow, Russia

2 National Research Center for Preventive Medicine, Moscow, Russia
}

of the genes studied can be considered as the main gene associated with CAD. However, the insertion/ deletion (I/D) polymorphism of the $A C E$ gene and the $\mathrm{R} 219 \mathrm{~K}$ and $\mathrm{R} 1587 \mathrm{~K}$ variants of $A B C A 1$ are associated with a higher likelihood of developing CAD, MI and angina among Russians who have siblings affected by CAD.

Key words: Candidate genes; Coronary artery disease (CAD); Polymorphism; Risk factor; Siblings; Transmission/disequilibrium test

\section{INTRODUCTION}

Atherosclerosis, the primary cause of coronary artery disease (CAD), is the leading cause of human morbidity and mortality in industrialized and developing countries [1]. The etiology of CAD is multifactorial, with many genetic and environmental determinants, including cigarette smoking, alcohol consumption, diabetes mellitus, obesity, aging, elevated blood pressure, elevated serum levels of low-density lipoprotein-cholesterol (LDL-C) and low serum levels of high-density lipoprotein-cholesterol (HDL-C).

Several candidate genes could determine individual susceptibility of blood vessels in the myocardium to develop atherosclerosis and CAD; a number of gene polymorphisms associated with an elevated risk of myocardial infarction (MI) have now been identified [2-4]. Numerous studies have revealed associations between elevated blood 
pressure and $\mathrm{CAD}$, and many candidate genes, particularly members of the renin-angiotensin system, have been investigated [5-10]. Both linkage and association studies have provided strong evidence for the role of the angiotensinogen (AGT) gene in hypertension in different populations [11-13]. The angiotensin-converting enzyme (ACE) gene plays a key role in the renin-angiotensin system and is associated with CAD [14]. The insertion/deletion (I/D) polymorphisms in the 16th intron of the ACE gene were identified in 1990 [15]. Analysis of ACE levels in the blood plasma of individuals of various populations demonstrated that homozygotes for the $\mathrm{D}$ allele had the highest ACE activity [14,16] and were at higher risk of developing $\mathrm{MI}$ and $\mathrm{CAD}[14,17]$.

The most significant risk factors for CAD are related to lipoprotein metabolism. Plasma lipoprotein disturbances are among the mostcommon biochemical abnormalities observed in patients with CAD [18]. The HDL-C level is strongly inversely correlated with developing CAD $[19,20]$. This antiatherogenic property of HDL is mainly due to its role in reverse cholesterol transport. The ATP binding cassette transporter 1 (ABCA1) protein has been identified as a mediator of cholesterol efflux [21,22]. ABCA1 stimulates cholesterol and phospholipid efflux to apolipoprotein A1 (the main component of HDL) and may act as a cholesterol/phospholipid flippase at the plasma membrane level (for reviews see $[23,24]$ ).

Several common polymorphisms have been reported in the coding and promoter regions of the $A B C A 1$ gene $[25,26]$. Some are associated with altered plasma lipid levels and with the development of CAD. For example, the R219K polymorphism is associated with progression of atherosclerosis and with elevated triglyceride (TG) and HDL-C levels in familial hypercholesterolemia patients from Spain [27]. Other single-nucleotide polymorphisms in the coding region had milder effects on plasma lipids and atherosclerosis [25].

Nitric oxide (NO) is a cell signaling molecule that plays an important role in physiological processes such as regulation of the vascular system, neurotransmission and various homeostatic events. It may exhibit either atherogenic or atheroprotective effects, depending on its source. Thus, the vasodilator function of $\mathrm{NO}$ produced by endothelial NO synthase (eNOS) is protective. Deletion of the eNOS gene in a background of apoE deficiency results in hypertension and increased atherosclerosis [28]. Several polymorphisms have been found in the eNOS gene [29], and some have been associated with increased cardiovascular risk [30,31].

Ephrins (EFNs) are cell-surface ligands of ephedrine receptor tyrosine kinases. They are classified into A and B subfamilies; EFNBs comprise three transmembrane proteins (EFNB1-3), which are capable of reverse transmission of signals into cells. Such functions are well demonstrated in the central nervous system, during angiogenesis and in intestinal development and remodeling [32-36]. EFNB3 plays a role in cardiovascular development [34].

In this study, we analyzed polymorphisms in the genes for ABCA1, ACE, AGT, eNOS and EFNB3 in 85 Russian patients with angiography-proven CAD and 100 of their siblings.

\section{MATERIALS AND METHODS}

Study Subjects. We recruited 85 Russian subjects among patients who attended the All-Russian Center for Preventive Medicine, Moscow, Russia, for CAD treatment. Inclusion required at least $50 \%$ stenosis in one or more major coronary arteries. We also analyzed 100 full siblings of these patients. Informed consent was provided by the participants before the investigations and the study was approved by the local Ethics Committee. Some clinical and biochemical characteristics of patients and their siblings are presented in Table 1.

Assessment of Coronary Artery Disease. Computer-assisted quantitative coronary angiography was assessed using a vessel score and a stenosis score. The former was the number of coronary vessels with significant stenosis $(60 \%$ or greater reduction in lumen diameter) and ranged from 0 to 3 . The latter was calculated according to a modified Gensini method [37], in which the most severe stenosis in each of eight segments was assigned to grade 1 if there was $1-49 \%$ reduction in lumen diameter, grade 2 for $50-74 \%$, grade 3 for $75-99 \%$ and grade 4 for total occlusion. The scores in all of the eight segments were added to give a total out of a theoretical maximum of 32 .

Plasma Lipid and Lipoprotein Measurements. Blood samples were collected from subjects after a minimal 10-hour fast. Aliquots of plasma were frozen at $-20^{\circ} \mathrm{C}$ before measurement of lipid, lipoprotein and apolipoprotein levels. Total cholesterol, HDL-C 
Table 1. Clinical and biochemical data of the proband and sibling groups under study.

\begin{tabular}{|c|c|c|c|}
\hline Parameters & Probands & Siblings & $p$ \\
\hline Number & 85 & 100 & - \\
\hline Height $(\mathrm{cm})$ & $172.4 \pm 7.7$ & $168.7 \pm 8.8$ & $N S$ \\
\hline Weight (kg) & $79.2 \pm 12.4$ & $77.8 \pm 11.9$ & $N S$ \\
\hline$B M I(\mathrm{~kg} / \mathrm{m} 2)$ & $27.0 \pm 3.0$ & $27.0 \pm 4.0$ & $N S$ \\
\hline Age (years) & $55.1 \pm 8.2$ & $53.2 \pm 7.8$ & $N S$ \\
\hline Smokers & $52(61.0 \%)$ & $39(39.0 \%)$ & $N S$ \\
\hline Familial history of CAD & $65(77.0 \%)$ & $76(76.0 \%)$ & $N S$ \\
\hline Arterial hypertension & $55(65.0 \%)$ & $51(51.0 \%)$ & 0.062 \\
\hline Diabetes mellitus & $10(12.0 \%)$ & $10(10.0 \%)$ & $N S$ \\
\hline Total cholesterol (mg/dL) & $232.3 \pm 38.0$ & $237.6 \pm 44.4$ & $N S$ \\
\hline$V L D L-C(m g / d L)$ & $29.6 \pm 13.0$ & $25.5 \pm 11.4$ & $N S$ \\
\hline$L D L-C(m g / d L)$ & $161.9 \pm 37.7$ & $164.0 \pm 36.9$ & $N S$ \\
\hline$H D L-C(m g / d L)$ & $43.8 \pm 9.7$ & $48.6 \pm 12.8$ & $N S$ \\
\hline$T G(m g / d L)$ & $137.8 \pm 67.3$ & $126.5 \pm 55.6$ & $N S$ \\
\hline
\end{tabular}

NS: not significant.

and TG levels were measured using enzymatic assay kits from Roche Diagnostics (Basel, Switzerland). HDL-C was measured as the level of cholesterol that remained in the supernatant after precipitation of the apoB-containing lipoproteins with dextran sulfatemagnesium. LDL-C was calculated using the equation of Friedewald et al. [38].

Genotyping. DNA was extracted by standard methods using proteinase $\mathrm{K} /$ phenol/chloroform treatment [39]. The polymorphism for each gene was determined by polymerase chain reaction (PCR) amplification and restriction enzyme cleavage. Genomic DNA $(0.1 \mu \mathrm{g})$ was amplified in $20 \mu \mathrm{L}$ of reaction mixture containing $5 \mathrm{pM}$ of each primer, $1 \mathrm{mM}$ of each dNTP, $2 \mu \mathrm{L}$ of $10 \times$ reaction buffer [500 mM Tris-HCl, $\mathrm{pH} 8.8,150 \mathrm{mM}\left(\mathrm{NH}_{4}\right)_{2} \mathrm{SO}_{4}$,
$50 \mathrm{mM} \mathrm{MgCl}_{2}, 2 \mathrm{mg} / \mathrm{mL}$ BSA, $0.1 \%$ Tween and $0.1 \%$ gelatin] and 0.5 units Taq DNA polymerase. After the DNA had been denatured for $5 \mathrm{~min}$. at $95^{\circ} \mathrm{C}$, the reaction mixture was subjected to 30 cycles of denaturation for $1 \mathrm{~min}$. at $95^{\circ} \mathrm{C}$, annealing for $1 \mathrm{~min}$. and extension for $1 \mathrm{~min}$. at $72^{\circ} \mathrm{C}$. The polymorphism was detected by digestion of the PCR-amplified fragment with particular restriction enzymes, separation on $6 \%$ polyacrylamide gels and visualization of fragments with ethidium bromide staining. The forward and reverse primers, restriction enzymes and fragment size for each locus are shown in Table 2.

Statistical Analysis. Statistical analysis was performed using the software STATISTICA, version 6.0. The linkage between CAD and each of the genes

Table 2. Forward and reverse primers, restriction enzymes and fragment size for each analyzed locus.

\begin{tabular}{|c|c|c|c|c|}
\hline Polymorphism & $\begin{array}{l}\text { Forward Oligo }\left(5^{\prime} \rightarrow 3^{\prime}\right) \\
\text { Reverse Oligo }\left(5^{\prime} \rightarrow 3^{\prime}\right)\end{array}$ & $\begin{array}{l}\text { Annealing } \\
\text { Temperature }\end{array}$ & Enzyme & $\begin{array}{l}\text { Product (in bp) Wild- } \\
\text { Type Allele Variant Allele }\end{array}$ \\
\hline I/D ACE & $\begin{array}{l}\text { CTGGAGACCACTCCCATCCTTTCT } \\
\text { GATGTGGCCATCACATTCGTCAGAT }\end{array}$ & $58^{\circ} \mathrm{C}$ & - & $\begin{array}{l}490 \text { in the presence, } 190 \text { in } \\
\text { the absence of insertion }\end{array}$ \\
\hline R219K ABCA1 & $\begin{array}{l}\text { GTATTTTTGCAAGGCTACCAGTTACATTTGACAA } \\
\text { GATTGGCTTCAGGATGTCCATGTTGGAA }\end{array}$ & $72^{\circ} \mathrm{C}$ & EcoNI & $\begin{array}{c}177 \\
107,70 \\
\end{array}$ \\
\hline R1587K ABCA1 & $\begin{array}{l}\text { CAGCTTGGGAAGATTTATGACAGGACTGGACACGA } \\
\text { ATGCCCCTGCCAACTTAC }\end{array}$ & $65^{\circ} \mathrm{C}$ & BssSI & $\begin{array}{c}114,31 \\
145\end{array}$ \\
\hline eNOS $4 a / 4 b$ & $\begin{array}{l}\text { AGGCCCTATGGTAGTGCCTTT } \\
\text { TCTCTTAGTGCTGTGGTCAT }\end{array}$ & $60^{\circ} \mathrm{C}$ & - & $\begin{array}{l}393 \\
420\end{array}$ \\
\hline M235T AGT & $\begin{array}{l}\text { GATGCGCACAAGGTCCTGTC } \\
\text { CAGGGTGCTGTCCACACTGGACCCC }\end{array}$ & $72^{\circ} \mathrm{C}$ & PsyI & $\begin{array}{c}303 \\
279,24\end{array}$ \\
\hline $\begin{array}{l}\text { BamHI polymorphism } \\
\text { of EFNB3 }(\mathrm{C} \rightarrow \mathrm{A})\end{array}$ & $\begin{array}{l}\text { TCAGAAGGAAGTAGGAAGGACTCAG } \\
\text { GAAGAGCCTCGGTTATGGGTATACA }\end{array}$ & $71^{\circ} \mathrm{C}$ & BamHI & $\begin{array}{c}90 \\
59,31\end{array}$ \\
\hline
\end{tabular}


studied was determined using the sibling transmission/ disequilibrium test (S-TDT), which is employed to analyze the distribution of allele variants and clinical characteristics in proband-sibling pairs. In the case of tight linkage, the z-score is usually greater than 2.47 for biallelic markers [40]. Allele frequencies were derived by gene counting, and checks for deviation of single-locus genotypes from HardyWeinberg equilibrium were based on Fisher's exact test. Comparisons of allele and genotype frequencies in the different groups under study were assessed by Fisher's exact test or by $\chi 2$ test. Whenever significant genotype associations are reported, relative risks $(R R \mathrm{~s})$ and their $95 \%$ confidence intervals $(95 \% \mathrm{CI})$ are provided. The $R R$ was calculated as: $R R=[\mathrm{A} /(\mathrm{A}+\mathrm{B})] /$ $[C /(C+D)]$, where $A$ and $B$ are the numbers of patients with and without genetic markers, respectively, and $\mathrm{C}$ and $\mathrm{D}$ are the numbers of healthy subjects with and without genetic markers, respectively. Confidence intervals were calculated as:

$\mathrm{CI}=\exp (\ln R R) \pm \mathrm{t} \sqrt{ }[\mathrm{B} / \mathrm{A}] /(\mathrm{B}+\mathrm{A})+[\mathrm{D} / \mathrm{C}] /(\mathrm{D}+\mathrm{C})$.

Correlations of physical and biochemical variables with different genotypes were determined by $\gamma$ correlation analysis after correction of the primary data for sex, body mass index (BMI) and age. Comparisons of variables between groups with different single-locus genotypes were determined by contingency table analysis for categorical measures and by independent Student's $t$ tests for continuous traits. Data without a normal distribution were $\log$ transformed before analysis. Comparisons of means values in groups with different single-locus genotypes were performed using the Newman-Keuls test.

\section{RESULTS}

Linkage Analysis. Both probands and their siblings were analyzed for the following polymorphisms: $\mathrm{R} 219 \mathrm{~K}$ and $\mathrm{R} 1587 \mathrm{~K}$ of the $A B C A 1$ gene, I/D polymorphism of $A C E, \mathrm{M} 235 \mathrm{~T}$ of $A G T$,
eNOS4a/4b and the C/A polymorphism of EFNB3. We first determined the possibility of linkage between CAD and each of the genes studied using the S-TDT (Table 3). No gene had a z-score greater than 2.47 for $\mathrm{CAD}$ or for its main manifestations of acute MI and angina. Thus, none of the five genes can be considered as the main gene associated with the disease, but these genes can affect disease development. Therefore, non parametric $\gamma$ correlation analysis was performed to assess the influence of the gene polymorphisms on the clinical and biochemical characteristics in the proband and sibling groups.

$A C E$ Gene Insertion/Deletion Polymorphism. Table 4 shows the $\gamma$ correlation between the $A C E$ I/D polymorphism and clinical and biochemical characters in CAD patients and their siblings. In the CAD group, this polymorphism correlated significantly with the level of HDL-C. In the sibling group, there were significant correlations with $\mathrm{CAD}$, acute MI, and the severity of angina, valvular atherosclerosis and left ventricular hypertrophy. Further analyses on the CAD group using the Newman-Keuls test did not reveal significant levels of correlation between the mean values of HDL-cholesterol in probands with different $A C E$ genotypes. Table 5 shows the distribution of $A C E$ genotypes for siblings with or without CAD, angina and MI. The DD genotype was significantly more prevalent among the siblings who had CAD than in the healthy siblings $(p=0.025)$. The $R R$ for developing CAD was 2.8 for siblings with the DD genotype (95\% CI 1.12-7.04). The DD genotype frequency was also higher in siblings with angina $(p=$ 0.028), for whom the $R R$ was 3.3 (95\% CI 1.14-9.59). The most significant results were observed for siblings with MI, where the DD genotype had a $R R$ of 5.5 (95\% CI 1.37-22.04), $p=0.018$.

In subjects with valvular atherosclerosis and left ventricular hypertrophy, $\chi 2$ testing did not reveal significant associations with any $A C E$ genotype. We conclude that the DD $A C E$ genotype in the Russian

Table 3. Linkage analysis of coronary artery disease and genes by sibling transmission/disequilibrium tests.

\begin{tabular}{|l|c|c|c|c|c|c|r|r|r|r|}
\hline \multicolumn{1}{|c|}{ Phenotype } & \multicolumn{2}{|c|}{ ABCA1 } & \multicolumn{2}{c|}{ ACE } & \multicolumn{2}{c|}{ AGT } & \multicolumn{2}{c|}{ eNOS } & \multicolumn{2}{c|}{ eFNB3 } \\
\hline & Z Score & $p$ & $Z$ Score & $\boldsymbol{p}$ & Z Score & $\boldsymbol{p}$ & Z Score & $p$ & Z Score & $p$ \\
\hline CAD & 0.28 & 0.64 & 0.57 & 0.55 & 1.42 & 0.27 & 0.97 & 0.32 & 0.03 & $>0.9$ \\
\hline MI & 0.37 & 0.60 & 0.66 & 0.49 & 0.22 & 0.67 & 0.97 & 0.32 & 0.85 & 0.44 \\
\hline Angina & 0.14 & 0.70 & 0.89 & 0.32 & 0.59 & 0.55 & 1.36 & 0.29 & 0.03 & $>0.9$ \\
\hline
\end{tabular}


Table 4. Correlation between the ACE gene insertion/deletion polymorphism, clinical and biochemical data of coronary artery disease patients and siblings by non parametric $\gamma$ correlation analysis.

\begin{tabular}{|l|c|c|}
\hline Phenotypes & \multicolumn{2}{|c|}{ Correlation Coefficient $\gamma$} \\
\hline CAD & Probands & Siblings \\
\hline MI & - & $0.354^{\mathrm{a}}$ \\
\hline Angina severity & 0.003 & $0.453^{\mathrm{a}}$ \\
\hline Arterial hypertension & -0.346 & $0.374^{\mathrm{a}}$ \\
\hline Left ventricle hypertrophy & -0.427 & 0.079 \\
\hline Septum hypertrophy & 0.003 & $0.362^{\mathrm{a}}$ \\
\hline Valve atherosclerosis & -0.294 & -0.072 \\
\hline LDL-C & 0.173 & $0.275^{\mathrm{a}}$ \\
\hline HDL-C & -0.053 & 0.043 \\
\hline TG & $0.240^{\mathrm{a}}$ & -0.132 \\
\hline Vessel index & -0.174 & 0.110 \\
\hline Stenosis index & 0.017 & - \\
\hline Occlusion & -0.028 & - \\
\hline
\end{tabular}

${ }^{a}$ Statistically significant correlation $(p<0.05)$.

population may be a risk factor for CAD, $\mathrm{MI}$ and angina, particularly for individuals having a siblings affected by CAD.

R219K and R1587 KPolymorphisms of $A B C A 1$. We tested for two common coding single-nucleotide polymorphisms of the $A B C A 1$ gene, i.e., $\mathrm{R} 219 \mathrm{~K}$ and R1587K. Table 6 shows the $\gamma$ correlations between the R219K polymorphism and clinical and biochemical data in patients and siblings. In the patient group, this polymorphism correlates with angina, LDL-C level, and especially with parameters that affect the sclerosis of coronary arteries. In the sibling group, there was a correlation with the incidence of CAD by itself, as well as with angina, hypertension and very low-density lipoprotein-cholesterol (VLDL-C) and TG levels.

For further analysis of correlations, we combined the RK heterozygotes and KK homozygotes into one genotype group because of the scarcity of individuals with the latter genotype. Figure 1 shows that the index of stenosis was significantly higher in subjects with the RK or KK genotypes than in those with only the RR genotype. Patients with the KK and RK genotypes more frequently showed in two or three vessel lesions

Table 5. Distribution of genotypes at $A C E$ gene insertion/deletion polymorphisms in a sibling group either with or without coronary artery disease, angina and myocardium infarction.

\begin{tabular}{|l|c|c|c|c|c|c|}
\hline \multirow{2}{*}{} & \multicolumn{2}{|c|}{ CAD } & \multicolumn{2}{c|}{ Angina } & \multicolumn{2}{c|}{ MI } \\
\cline { 2 - 7 } & With & Without & With & Without & With & Without \\
\hline D/D Genotype & $43.0 \%$ & $21.0 \%$ & $48.0 \%$ & $21.0 \%$ & $60.0 \%$ & $21.0 \%$ \\
\hline I/I Genotype & $57.0 \%$ & $79.0 \%$ & $52.0 \%$ & $79.0 \%$ & $40.0 \%$ & $79.0 \%$ \\
\hline$p$ Value & \multicolumn{2}{|c|}{$0.025^{\mathrm{a}}$} & \multicolumn{2}{c|}{$0.028^{\mathrm{a}}$} & \multicolumn{2}{c|}{$0.018^{\mathrm{a}}$} \\
\hline$R R$ & \multicolumn{2}{|c|}{2.8} & \multicolumn{2}{c|}{3.3} & \multicolumn{2}{c|}{5.5} \\
\hline $95 \%$ CI & \multicolumn{2}{|c|}{$1.12-7.04$} & \multicolumn{2}{c|}{$1.14-9.59$} & \multicolumn{2}{c|}{7.22 .04} \\
\hline D Allele & $58.0 \%$ & $46.0 \%$ & $60.0 \%$ & $46.0 \%$ & $75.0 \%$ & $46.0 \%$ \\
\hline I Allele & $42.0 \%$ & $54.0 \%$ & $40.0 \%$ & $54.0 \%$ & $25.0 \%$ & $54.0 \%$ \\
\hline$p$ Value & \multicolumn{2}{|c|}{0.082} & \multicolumn{2}{c|}{0.087} & \multicolumn{2}{c|}{$0.015^{\mathrm{a}}$} \\
\hline
\end{tabular}

${ }^{\text {a }}$ Statistically significant results. 
Table 6. Correlation between two $A B C A 1$ gene polymorphisms, clinical and biochemical data of coronary artery disease patients and siblings by non parametric $\gamma$ correlation analyses.

\begin{tabular}{|l|c|c|c|c|}
\hline \multirow{2}{*}{ Phenotypes } & \multicolumn{3}{|c|}{ Correlation Coefficient $\gamma$} \\
\cline { 2 - 5 } & \multicolumn{2}{|c|}{ R219K } & \multicolumn{2}{c|}{ R1587K } \\
\cline { 2 - 5 } & Probands & Siblings & - & $0^{2}$ \\
\hline CAD & - & $-0.319^{\mathrm{a}}$ & $0.071^{\mathrm{a}}$ \\
\hline MI & -0.256 & -0.179 & 0.016 & $0.951^{\mathrm{a}}$ \\
\hline Angina severity & $-0.252^{\mathrm{a}}$ & $-0.400^{\mathrm{a}}$ & 0.319 & $0.493^{\mathrm{a}}$ \\
\hline Arterial hypertension & -0.256 & $-0.347^{\mathrm{a}}$ & 0.102 & 0.171 \\
\hline Valve atherosclerosis & $-0.482^{\mathrm{a}}$ & -0.192 & 0.124 & -0.172 \\
\hline VLDL-C & 0.046 & $-0.244^{\mathrm{a}}$ & 0.105 & 0.043 \\
\hline LDL-C & $-0.232^{\mathrm{a}}$ & -0.016 & 0.012 & 0.006 \\
\hline HDL-C & 0.035 & 0.129 & 0.096 & 0.092 \\
\hline TG & 0.096 & $-0.272^{\mathrm{a}}$ & 0.043 & 0.071 \\
\hline Vessel index & $-0.373^{\mathrm{a}}$ & - & 0.076 & - \\
\hline Stenosis index & $-0.409^{\mathrm{a}}$ & - & 0.161 & - \\
\hline Occlusion & $-0.326^{\mathrm{a}}$ & - & & - \\
\hline
\end{tabular}

${ }^{\text {a }}$ Statistically significant correlation $(p<0.05)$.

$(p=0.001)$. Patients with the RR genotype more frequently had lesions in one vessel (Table 7).

Similar studies were carried out in the sibling group. Table 8 shows the genotype distribution in siblings with and without $\mathrm{CAD}$, angina and arterial hypertension. The combination of genotype KK with

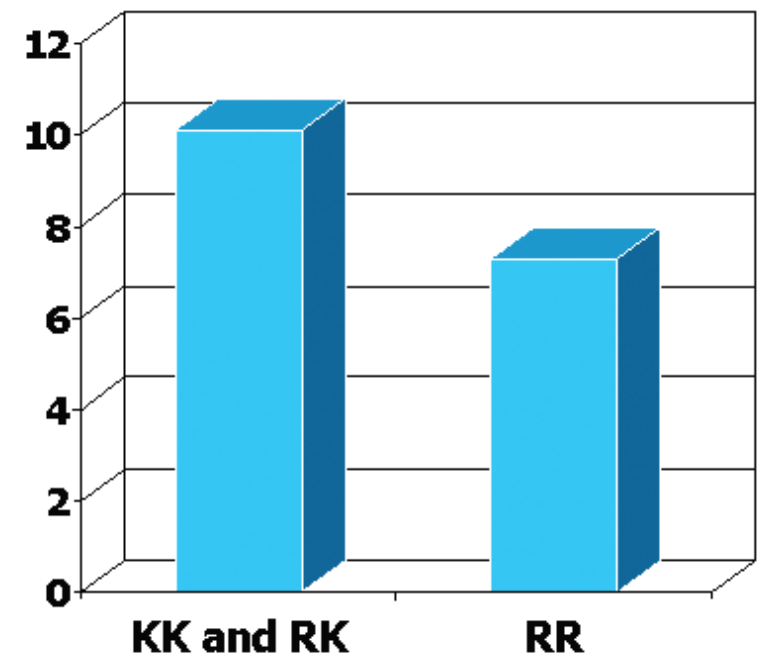

Figure 1. The R219K ABCA1 gene polymorphism and mean stenosis index in CAD patients. Stenosis index for patients with $\mathrm{KK}$ and RK genotypes is significantly elevated compared to patients with the RR genotype $(p=0.004)$.
RK was frequent among siblings with CAD; the $R R$ being 2.38 (95\% CI 1.02-5.80), $p=0.044$. Results were similar for arterial hypertension $(R R=2.87 ; 95 \%$ CI 1.26-6.56), $(p=0.023)$ and angina $(p=0.027)$. The $R R$ value for siblings with the KK and RK genotypes was 3.3 (95\% CI 1.08-10.23).

Results for the polymorphic R1587K site in this gene using non parametric $\gamma$ correlation analysis are shown in Table 6. For probands with CAD, this polymorphism did not influence the main CAD clinical presentations (such as MI and the severity of angina) or the degree of coronary artery atherosclerotic lesions (vessel index, stenosis index or coronary artery occlusions). There were no apparent effects of this polymorphism on the plasma lipid spectrum. However, among the sibling group, there were very significant correlations between the R1587K polymorphism and CAD, MI and angina. Thus, the increased risk of CAD and its main manifestations is associated with $\mathrm{RR}$ genotypes. The $R R$ value for developing $\mathrm{CAD}$ among subjects with RR genotype was 4.88 (95\% CI 4.14-7.62), for MI it was $6.18(95 \%$ CI 2.26-10.1) and for angina, 3.69 (95\% CI 2.00-5.18) (Table 9).

Thus, among this Russian population, the $A B C A 1$ gene $\mathrm{R} 1587 \mathrm{~K}$ polymorphism was associated with a 
Table 7. The R219K ABCA1 gene polymorphism and artery measurements by coronary angiography. Vessel index is the number of vessels with stenosis of more than $50 \%: 1=$ one vessel; $2=$ two vessels; $3=$ three vessels.

\begin{tabular}{|l|c|c|c|c|}
\hline \multirow{3}{*}{ Vessel index } & & KK and RR Genotypes & RR Genotype & $p$ \\
\cline { 2 - 4 } & 1 & $11.0 \%$ & $41.0 \%$ & \multirow{2}{*}{0.001} \\
\cline { 2 - 4 } & 2 & $48.0 \%$ & $27.0 \%$ & \\
\hline \multirow{2}{*}{ Occlusion } & With & $41.0 \%$ & $32.0 \%$ & 0.023 \\
\cline { 2 - 5 } & Without & $62.0 \%$ & $38.0 \%$ & $55.0 \%$ \\
\hline
\end{tabular}

Table 8. Genotype distribution at the R219K polymorphism of the ABCA1 gen in the sibling group either with or without coronary artery disease, angina and arterial hypertension.

\begin{tabular}{|c|c|c|c|c|c|c|}
\hline & \multicolumn{2}{|c|}{ CAD } & \multicolumn{2}{|c|}{ Angina } & \multicolumn{2}{|c|}{ Arterial Hypertension } \\
\hline & With & Without & With & Without & With & Without \\
\hline $\mathrm{K} 219 \mathrm{~K}$ and R219K genotypes & $67.0 \%$ & $46.0 \%$ & $74.0 \%$ & $46.0 \%$ & $63.0 \%$ & $35.0 \%$ \\
\hline R219R genotype & $33.0 \%$ & $54.0 \%$ & $26.0 \%$ & $54.0 \%$ & $37.0 \%$ & $65.0 \%$ \\
\hline$p$ Value & \multicolumn{2}{|c|}{$0.044^{\mathrm{a}}$} & \multicolumn{2}{|c|}{$0.027^{\mathrm{a}}$} & \multicolumn{2}{|c|}{$0.023^{\mathrm{a}}$} \\
\hline RR & \multicolumn{2}{|c|}{2.38} & \multicolumn{2}{|c|}{3.3} & \multicolumn{2}{|c|}{2.87} \\
\hline $95 \% \mathrm{CI}$ & \multicolumn{2}{|c|}{$1.02-5.80$} & \multicolumn{2}{|c|}{$1.08-10.23$} & \multicolumn{2}{|c|}{$1.26-6.56$} \\
\hline $219 \mathrm{~K}$ allele & $43.0 \%$ & $27.0 \%$ & $47.0 \%$ & $28.0 \%$ & $39.0 \%$ & $24.0 \%$ \\
\hline 219R allele & $57.0 \%$ & $73.0 \%$ & $53.0 \%$ & $72.0 \%$ & $61.0 \%$ & $76.0 \%$ \\
\hline$p$ Value & \multicolumn{2}{|c|}{$0.019^{\mathrm{a}}$} & \multicolumn{2}{|c|}{$0.007^{\mathrm{a}}$} & \multicolumn{2}{|c|}{$0.019^{\mathrm{a}}$} \\
\hline
\end{tabular}

a Statistically significant result.

Table 9. Genotype distribution at the R1587K polymorphism of the $A B C A 1$ gene in the sibling group either with or without coronary artery disease, myocardium infarction and angina.

\begin{tabular}{|c|c|c|c|c|c|c|}
\hline & \multicolumn{2}{|c|}{ CAD } & \multicolumn{2}{|c|}{ MI } & \multicolumn{2}{|c|}{ Angina } \\
\hline & With & Without & With & Without & With & Without \\
\hline $\mathrm{K} 1587 \mathrm{~K}$ and $\mathrm{R} 1587 \mathrm{~K}$ genotypes & $13.0 \%$ & $43.0 \%$ & $9.0 \%$ & $36.0 \%$ & $15.0 \%$ & $39.0 \%$ \\
\hline R1587R genotype & $87.0 \%$ & $57.0 \%$ & $91.0 \%$ & $64.0 \%$ & $85.0 \%$ & $61.0 \%$ \\
\hline$p$ Value & \multicolumn{2}{|c|}{$0.043^{\mathrm{a}}$} & \multicolumn{2}{|c|}{$0.049^{\mathrm{a}}$} & \multicolumn{2}{|c|}{$0.045^{\mathrm{a}}$} \\
\hline$R R$ & \multicolumn{2}{|c|}{4.88} & \multicolumn{2}{|c|}{6.18} & \multicolumn{2}{|c|}{3.59} \\
\hline $95 \% \mathrm{CI}$ & \multicolumn{2}{|c|}{$4.14-7.62$} & \multicolumn{2}{|c|}{$2.26-10.10$} & \multicolumn{2}{|c|}{$2.00-5.18$} \\
\hline $1587 \mathrm{~K}$ allele & $7.0 \%$ & $24.0 \%$ & $5.0 \%$ & $21.0 \%$ & $8.0 \%$ & $21.0 \%$ \\
\hline 1587R allele & $93.0 \%$ & $76.0 \%$ & $95.0 \%$ & $79.0 \%$ & $92.0 \%$ & $79.0 \%$ \\
\hline$p$ Value & \multicolumn{2}{|c|}{$0.005^{\mathrm{a}}$} & \multicolumn{2}{|c|}{$0.025^{\mathrm{a}}$} & \multicolumn{2}{|c|}{$0.047^{\mathrm{a}}$} \\
\hline
\end{tabular}

${ }^{\text {a }}$ Statistically significant result. 
Table 10. Correlation between clinical and biochemical data and the $A G T, e N O S, E F N B 3$ genes in coronary artery disease patients and their siblings by non parametric $\gamma$ correlation analyses.

\begin{tabular}{|l|c|c|c|c|c|c|}
\hline \multirow{2}{*}{ Phenotypes } & \multicolumn{7}{|c|}{ Correlation Coefficient $\gamma$} & \multicolumn{2}{c|}{ EFNB3 BamHI } \\
\cline { 2 - 7 } & \multicolumn{2}{|c|}{ M235T $\boldsymbol{A G T}$} & \multicolumn{2}{c|}{ 4a/4b $\boldsymbol{e N O S}$} & \multicolumn{2}{c|}{ Siblings } \\
\cline { 2 - 7 } & Probands & Siblings & Probands & Siblings & Probands & -0.139 \\
\hline CAD & - & -0.066 & - & 0.147 & - & -0.156 \\
\hline Myocardium infarction & 0.135 & 0.056 & 0.055 & 0.026 & -0.157 & -0.102 \\
\hline Angina & -0.102 & -0.214 & -0.072 & -0.015 & -0.007 & 0.327 \\
\hline Septum hypertrophy & -0.243 & $-0.446^{a}$ & -0.138 & -0.124 & 0.155 & -0.088 \\
\hline LDL-C & 0.144 & -0.198 & 0.103 & 0.023 & 0.119 & 0.016 \\
\hline HDL-C & 0.125 & 0.062 & -0.098 & $0.249^{a}$ & 0.007 & -0.018 \\
\hline TG & -0.073 & 0.014 & -0.093 & -0.129 & -0.023 & 0.088 \\
\hline Valve atherosclerosis & 0.221 & 0.070 & 0.358 & 0.190 & 0.263 & - \\
\hline Vessel index & 0.159 & - & 0.113 & - & 0.125 & - \\
\hline Stenosis index & 0.035 & - & -0.029 & - & 0.090 & - \\
\hline Occlusion & -0.054 & - & -0.128 & - & -0.062 & - \\
\hline
\end{tabular}

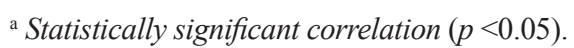

clear risk of developing CAD for individuals with a family history of CAD. Evidently, the rare allele $\mathrm{K}$ is protective and reduces the risk of CAD.

Analysis of eNOS4a/4b, the M235T Polymorphism of $A G T$ and the C/A (BamHI) Polymorphism of $\boldsymbol{E F N B 3}$. Table 10 shows the $\gamma$ correlation test for the $A G T$ polymorphism of M235T, and for eNOS minisatellite $4 \mathrm{a} / 4 \mathrm{~b}$ and EFNB3 BamHI polymorphism. For each polymorphism, there appeared to be at least one significant correlation with a given disease characteristic. However, further analyses by $\chi 2$ and Newman-Keuls tests did not reveal any significant correlations of clinical parameters with any of the corresponding genotypes.

\section{DISCUSSION}

We analyzed the polymorphisms of several genes in patients with angiography-proven CAD and their siblings in a Russian population. The S-TDT evaluation found no linkage between $\mathrm{CAD}$ and each of these genes; the z-score was below 2.47, so none of these genes can be considered as the main cause of the disease. However, two genes, $A C E$ and $A B C A 1$, showed association with the risk of developing $\mathrm{CAD}$ and its main clinical presentations for those subjects who had siblings affected by CAD. The I/D polymorphism of the $A C E$ gene correlated significantly with $\mathrm{CAD}$ and its clinical presentations (angina and MI) in the sibling group but not in the patient group. Among siblings with the DD genotype, the $R R$ of developing CAD was 2.8 (95\% CI 1.12-7.04), of angina 3.3 (95\% CI 1.14-9.59) and of MI 5.5 (95\% CI 1.37-22.04).

Analysis of the blood plasma ACE level of other populations and in individuals with different genotypes demonstrated that the homozygotes for the D allele had the highest levels and also an increased risk of developing CAD and MI [14,16,17]. However, the results are controversial and do not provide a clear understanding of the role of this polymorphism in the genesis of these diseases $[41,42]$.

We found that the $\mathrm{R} 219 \mathrm{~K}$ polymorphism of the $A B C A 1$ gene correlated with the incidence of angina, with LDL-C levels and especially with parameters affecting sclerosis of the coronary arteries in the patient group. The K219K and R219K genotypes were associated with more severe atherosclerotic lesions of the coronary arteries than the R219R genotype. In addition, allele $219 \mathrm{~K}$ and its related genotypes were associated with higher risks for CAD by itself, and for angina and arterial hypertension in the sibling group.

Many studies are available with analyses of different polymorphism of $A B C A 1$ gene. Clee et al. [25] investigated phenotypic effects of the R $219 \mathrm{~K}$ 
polymorphism in Dutch subjects with confirmed CAD. Carriers of the $219 \mathrm{~K}$ allele had reduced severity of atherosclerosis and fewer coronary events. The $219 \mathrm{~K}$ allele was associated with decreased TGs and a trend to increased HDL level. Sun et al. [43] investigated the association of the R $219 \mathrm{~K}$ polymorphism and the susceptibility to CAD in Chinese population. Genotypes were determined in 248 CAD-free controls and $224 \mathrm{CAD}$ cases. Carriers of the $219 \mathrm{~K}$ allele (R219K and K219K genotypes) had a significantly decreased risk for CAD compared with wild-type genotype R219R. Plasma HDL-C in 219K allele carriers was higher than those in $219 \mathrm{~K}$ non carriers. Similar results have been reported from Germany [44]. Balcerzyk et al. [45] did not show any association between the R219K polymorphism of the $A B C A 1$ gene and $\mathrm{CAD}$, but revealed that it acts cumulatively and synergistically with the $\mathrm{G} \rightarrow \mathrm{C}$ polymorphism in intron 7 of the PPARA gene in determining the risk of CAD. Here, in our Russian population, carriers of allele $219 \mathrm{~K}$ and its related genotypes, were associated with higher risks for CAD by itself and also for angina and arterial hypertension. These contrary data suggest that the $\mathrm{R} 219 \mathrm{~K}$ polymorphism is probably a marker which is associated with other functionally significant polymorphisms that influence CAD.

There were very significant associations between the R1587K genotype and the risk of developing CAD, MI and angina among the siblings of patients with CAD. Thus, the increased risk of CAD and its main manifestations is associated with the R1587 allele. The $R R$ for developing CAD in the carriers of genotypes R1587R and R1587K was 4.88 (95\% CI 4.14-7.62). Evidently, the rare allele $1587 \mathrm{~K}$ is protective and reduces the risk of CAD. Such a correlation has not been described previously. Clee et al. [25] did not find any correlation of this polymorphism with $\mathrm{CAD}$ or with the characteristics of atherosclerotic vessel lesions (such as effective arterial diameter or minimum arterial diameter) for a Dutch population. In addition, there was no association of the $\mathrm{R} 1587 \mathrm{~K}$ polymorphism with MI among populations in Northern Ireland or Scotland [4]. Clearly, there are ethnic differences in the influence of the R $1587 \mathrm{~K}$ polymorphism on the risk of developing CAD.

The association of the R1587K polymorphism with CAD in our sample was not connected to its effect on plasma lipid levels. An association between plasma lipid level and the $\mathrm{R} 1587 \mathrm{~K} A B C A 1$ gene variants was described by Clee et al. [25]. In a Danish population, low HDL-C levels were found in patients with K1587K and $\mathrm{R} 1587 \mathrm{~K}$ genotypes (which lowers the risk of developing CAD in our Russian population). Only an association of the $\mathrm{R} 1587 \mathrm{~K}$ polymorphism with apoA1 level was found in samples from Glasgow and Belfast [4]. Therefore, the association between the R1587K polymorphism and plasma lipid spectrum may be population-specific. This suggests that the R1587K polymorphism may be an independent genetic marker of CAD risk and MI for Russians with a family history of cardiovascular diseases.

It is especially interesting that this $\mathrm{R} 1587 \mathrm{~K}$ polymorphism was not in significant linkage disequilibrium with other $A B C A 1$ gene polymorphic sites, in particular with the $\mathrm{R} 219 \mathrm{~K}$ polymorphic site [25]. These two polymorphisms are localized in different regions of the $A B C A 1$ gene and possibly determine different functions of ABCA1 protein. Further research conducted in a large group of patients should help clarify the importance of this association in different populations.

Our analyses did not reveal any significant correlations between the M235T polymorphism of the $A G T$ gene and higher risk of CAD development. Moreover, Rodrigues-Perez et al. [46] detected that the $235 \mathrm{~T}$ allele was significantly more frequent in patients with CAD than in controls. Buraczynska et al. [47] revealed that the T235T genotype of the $A G T$ gene M235T polymorphism was associated with an increased risk of CAD and MI. At the same time, Sekuri et al. [48] demonstrated that increased premature CAD risk is associated with higher frequencies of the $A G T \mathrm{M} 235 \mathrm{M}$ genotype. No evidence was found for an association of the eNOS minisatellite $4 \mathrm{a} / 4 \mathrm{~b}$ polymorphism with $\mathrm{CAD}$ in our research and in investigations by Gardemann et al. [49]. However, another polymorphism of this gene was found to be associated with CAD and MI $[49,50]$. Schneider et al. [51] supposed that the observed association between the Glu258Asp polymorphism of the eNOS gene and various cardiovascular disorders could be explained on the basis of altered endothelium-dependent vasodilatation. However, they did not reveal a major effect of the Glu258Asp polymorphism of the eNOS gene on endothelium-dependent vasodilatation.

These contrary data suggest that the mechanism of CAD development still remains completely unknown. Future analyses will promote our deeper 
understanding of the contribution of genetic factors to the pathogenesis of the disease.

\section{ACKNOWLEDGMENTS}

This study was supported by grants from the programs "Molecular and Cellular Biology" and "Basic Sciences in Medicine" of the Russian Academy of Sciences; the Federal Support of Leading Scientific Schools of the Russian Ministry of Science and Technology; and the Russian Basic Research Foundation.

\section{REFERENCES}

1. The World Health Report 2003e. Geneva, Switzerland: World Health Organization 2003 (http:// www.who. int/whr/2003/en/Annex2-en.pdf).

2. Araujo MA, Goulart LR, Cordeiro ER, Gatti RR, Menezes BS, Lourenco C, Silva HD. Genotypic interactions of renin-angiotensin system genes in myocardial infarction. Int J Cardiol 2005; 103(1): 27-32.

3. Fernández-Arcás N, Dieguez-Lucena JL, Muñoz-Morán E, Ruiz-Galdón M, Espinosa-Caliani S, Aranda-Lara P, Rius-Diaz F, Gaitán-Arroyo MJ, De Teresa-Galván E, Reyes-Engel A. Both alleles of the M235T polymorphism of the angiotensinogen gene can be a risk factor for myocardial infaction. Clin Genet 2001; 60(1): 52-57.

4. Tregouet DA, Ricard S, Nicaud V, Arnould I, Soubigou S, Rosier M, Duverger N, Poirier O, Mace S, Kee F, Morrison C, Denefle P, Tiret L, Evans A, Deleuze JF, Cambien F. In-depth haplotype analysis of ABCA1 gene polymorphisms in relation to plasma ApoA1 levels and myocardial infarction. Arterioscler Thromb Vasc Biol 2004; 24(4): 775-781.

5. Acarturk E, Attila G, Bozkurt A, Akpinar O, Matyar S, Seydaoglu G. Insertion/deletion polymorphism of the angiotensin converting enzyme gene in coronary artery disease in southern Turkey. $\mathrm{J}$ Biochem Mol Biol 2005; 38(4): 486-490.

6. Buraczynska M, Pijanowski Z, Spasiewicz D, Nowicka T, Sodolski T, Widomska-Czekajska T, Ksiazek A. Renin-angiotensin system gene polymorphisms: assessment of the risk of coronary heart disease. Kardiol Pol 2003; 58(1): 1-9.

7. Lanz JR, Pereira AC, Lemos PA, Martinez E, Krieger JE. Angiotensinogen M235T polymorphism is associated with coronary artery disease severity. Clin Chim Acta 2005; 362(1-2): 176-181.

8. Nacak M, Davutoglu V, Soydinc S, Dinckal H, Turkmen S, Erbagci B, Akcay M, Aynacioglu S. Association between angiotensin converting enzyme gene polymorphism and coronary artery disease in individuals of the South-Eastern Anatolian population. Anadolu Kardiyol Derg 2004; 4(1): 45-51.

9. Shi YP, Meng WH, Shan J, Fu GS, Xu G. Polymorphism of angiotensin converting enzyme in Han populations and its relevance to the severity of coronary atherosclerosis (in Chinese). Zhejiang Da Xue Xue Bao Yi Xue Ban 2006; 35(3): 287-291.

10. Tsai CT, Hwang JJ, Ritchie MD, Moore JH, Chiang FT, Lai LP, Hsu KL, Tseng CD, Lin JL, Tseng YZ. Renin-angiotensin system gene polymorphisms and coronary artery disease in a large angiographic cohort: detection of high order gene-gene interaction. Atherosclerosis 2007; 195(1): 172-180.

11. Caulfield M, Lavender P, Farrall M, Munroe P, Lawson M, Turner P, Clark AJ. Linkage of the angiotensinogen gene to essential hypertension. N Engl J Med 1994; 330(23): 1629-1633.

12. Caulfield M, Lavender P, Newell-Price J, Farrall M, Kamdar S, Daniel H, Lawson M, De Freitas P, Fogarty P, Clark AJ. Linkage of the angiotensinogen gene locus to human essential hypertension in African Caribbeans. J Clin Invest 1995; 96(2): 687-692.

13. Walker WG, Whelton PK, Saito H, Russell RP, Hermann J. Relationship between blood pressure and renin, renin substrate, angiotensin II, aldosterone and urinary sodium and potassium in 574 ambulatory subjects. Hypertension 1979; 1(3): 287-291.

14. Staessen JA, Wang JG, Ginocchio G, Petrov V, Saavedra AP, Soubrier F, Vlietinck R, Fagard R. The deletion/insertion polymorphism of the angiotensin converting enzyme gene and cardiovascular-renal risk. J Hypertens 1997; 15(12): 1579-1592.

15. Rigat B, Hubert C, Alhenc-Gelas F, Cambien F, Corvol P, Soubrier F. An insertion/deletion polymorphism in the angiotensin I-converting enzyme gene accounting for half the variance of serum enzyme levels. J Clin Invest 1990; 86(4): 1343-1346.

16. Tiret L, Rigat B, Visvikis S, Breda C, Corvol P, Cambien F, Soubrier F. Evidence, from combined segregation and linkage analysis, that a variant of the angiotensin I-converting enzyme (ACE) gene controls plasma ACE levels. Am J Hum Genet 1992; 51(1): 197-205. 
17. Cambien F, Poirier O, Lecerf L, Evans A, Cambou JP, Arveiler D, Luc G, Bard JM, Bara L, Ricard S, Tiret L, Amouyel P, Alhenc-Gelas F, Soubrier F. Deletion polymorphism in the gene for angiotensinconverting enzyme is a potent risk factor for myocardial infarction. Nature 1992; 359(6396): 641-644.

18. Neaton JD, Wentworth D. Serum cholesterol, blood pressure, cigarette smoking, and death from coronary heart disease. Overall findings and differences by age for 316,099 white men. Multiple Risk Factor Intervention Trial Research Group. Arch Intern Med 1992; 152(1): 56-64.

19. Goldbourt U, Yaari S, Medalie JH. Isolated low HDL cholesterol as a risk factor for coronary heart disease mortality. A 21-year follow-up of 8000 men. Arterioscler Thromb Vasc Biol 1997; 17(1): 107-113.

20. Wilson PW, Abbott RD, Castelli WP. High density lipoprotein cholesterol and mortality. The Framingham Heart Study. Arteriosclerosis 1988; 8(6): 737-741.

21. Luciani MF, Denizot F, Savary S, Mattei MG, Chimini G. Cloning of two novel ABC transporters mapping on human chromosome 9. Genomics 1994; 21(1): 150-159.

22. Langmann T, Klucken J, Reil M, Liebisch G, Luciani MF, Chimini G, Kaminski WE, Schmitz G. Molecular cloning of the human ATP-binding cassette transporter 1 (hABC1): evidence for sterol-dependent regulation in macrophages. Biochem Biophys Res Commun 1999; 257(1): 29-33.

23. Oram JF. ATP-binding cassette transporter A1 and cholesterol trafficking. Curr Opin Lipidol 2002; 13(4): 373-381.

24. Schmitz G, Kaminski WE, Orso E. ABC transporters in cellular lipid trafficking. Curr Opin Lipidol 2000; 11(5): 493-501.

25. Clee SM, Zwinderman AH, Engert JC, Zwarts KY, Molhuizen HO, Roomp K, Jukema JW, van Wijland M, van Dam M, Hudson TJ, Brooks-Wilson A, Genest J Jr, Kastelein JJ, Hayden MR. Common genetic variation in ABCA1 is associated with altered lipoprotein levels and a modified risk for coronary artery disease. Circulation 2001; 103(9): 1198-1205.

26. Pullinger CR, Hakamata H, Duchateau PN, Eng C, Aouizerat BE, Cho MH, Fielding CJ, Kane JP. Analysis of hABC1 gene 5' end: additional peptide sequence, promoter region, and four polymorphisms. Biochem Biophys Res Commun 2000; 271(2): 451-455.
27. Cenarro A, Artieda M, Castillo S, Mozas P, Reyes G, Tejedor D, Alonso R, Mata P, Pocovi M, Civeira F, Spanish FH group. A common variant in the ABCA1 gene is associated with a lower risk for premature coronary heart disease in familial hypercholesterolaemia. J Med Genet 2003; 40(3): 163-168.

28. Knowles JW, Reddick RL, Jennette JC, Shesely EG, Smithies O, Maeda N. Enhanced atherosclerosis and kidney dysfunction in eNOS(-/-)Apoe(-/-) mice are ameliorated by enalapril treatment. J Clin Invest 2000; 105(4): 451-458.

29. Miyahara K, Kawamoto T, Sase K, Yui Y, Toda K, Yang LX, Hattori R, Aoyama T, Yamamoto Y, Doi Y, Ogoshi S, Hashimoto K, Kawai C, Sasayama S, Shizuta Y. Cloning and structural characterization of the human endothelial nitric-oxide-synthase gene. Eur J Biochem 1994; 223(3): 719-726.

30. Hingorani AD, Liang CF, Fatibene J, Lyon A, Monteith S, Parsons A, Haydock S, Hopper RV, Stephens NG, O'Shaughnessy KM, Brown MJ. A common variant of the endothelial nitric oxide synthase (Glu298 $\rightarrow$ Asp) is a major risk factor for coronary artery disease in the UK. Circulation 1999; 100(14): 1515-1520.

31. Shimasaki Y, Yasue H, Yoshimura M, Nakayama M, Kugiyama K, Ogawa H, Harada E, Masuda T, Koyama W, Saito Y, Miyamoto Y, Ogawa Y, Nakao K. Association of the missense Glu298Asp variant of the endothelial nitric oxide synthase gene with myocardial infarction. J Am Coll Cardiol 1998; 31(7): 1506-1510.

32. Wang HU, Anderson DJ. Eph family transmembrane ligands can mediate repulsive guidance of trunk neural crest migration and motor axon outgrowth. Neuron 1997; 18(3): 383-396.

33. Winslow JW, Moran P, Valverde J, Shih A, Yuan JQ, Wong SC, Tsai SP, Goddard A, Henzel WJ, Hefti F, Beck KD, Caras IW. Cloning of AL-1, a ligand for an Eph-related tyrosine kinase receptor involved in axon bundle formation. Neuron 1995; 14(5): 973-981.

34. Adams RH, Wilkinson GA, Weiss C, Diella F, Gale NW, Deutsch U, Risau W, Klein R. Roles of ephrinB ligands and EphB receptors in cardiovascular development: demarcation of arterial/venous domains, vascular morphogenesis, and sprouting angiogenesis. Genes Dev 1999; 13(3): 295-306.

35. Holder N, Klein R. Eph receptors and ephrins: 
effectors of morphogenesis. Development 1999; 126(10): 2033-2044.

36. Gale NW, Yancopoulos GD. Growth factors acting via endothelial cell-specific receptor tyrosine kinases: VEGFs, angiopoietins, and ephrins in vascular development. Genes Dev 1999; 13(9): 1055-1066.

37. Gensini GG. A more meaningful scoring system for determining the severity of coronary heart disease. Am J Cardiol 1983; 51(3): 606-607.

38. Friedewald WT, Levy RI, Fredrickson DS. Estimation of the concentration of low-density lipoprotein cholesterol in plasma, without use of the preparative ultracentrifuge. Clin Chem 1972; 18(6): 499-502.

39. Miller SA, Dykes DD, Polesky HF. A simple salting out procedure for extracting DNA from human nucleated cells. Nucleic Acids Res 1988; 16(3): 1215.

40. Spielman RS, Ewens WJ. A sibship test for linkage in the presence of association: the sib transmission/disequilibrium test. Am J Hum Genet 1998; 62(2): 450-458.

41. Chiang FT, Lai ZP, Chern TH, Tseng CD, Hsu KL, Lo HM, Tseng YZ. Lack of association between angiotensin-converting enzyme gene polymorphism and coronary heart disease in a Chinese population. Jpn Heart J 1997; 38(2): 227-236.

42. Agerholm-Larsen B, Nordestgaard BG, Tybjaerg-Hansen A. ACE gene polymorphism in cardiovascular disease: meta-analyses of small and large studies in whites. Arterioscler Thromb Vasc Biol 2000; 20(2): 484-492.

43. Sun P, Bo XP, Guo DP, Li XY, Hu ZB, Wang J, Li XR, Fan LM, Chen Q. Study on the association of ABCA1 gene common variants with the risk of coronary atherosclerotic heart disease (in Chinese). Zhonghua Xin Xue Guan Bing Za Zhi 2005; 33(7): 627-630.

44. Evans D, Beil FU. The association of the R219K polymorphism in the ATP-binding cassette transporter 1 (ABCA1) gene with coronary heart disease and hyperlipidaemia. J Mol Med 2003; 81(4): 264-270.
45. Balcerzyk A, Zak I, Krauze J. Synergistic effect between polymorphisms of PPARA and ABCA1 genes on the premature coronary artery disease. Acta Cardiol 2007; 62(3): 233-238.

46. Rodriguez-Perez JC, Rodriguez-Esparragon F, Hernandez-Perera O, Anabitarte A, Losada A, Medina A, Hernandez E, Fiuza D, Avalos O, Yunis C, Ferrario CM. Association of angiotensinogen $\mathrm{M} 235 \mathrm{~T}$ and $\mathrm{A}(-6) \mathrm{G}$ gene polymorphisms with coronary heart disease with independence of essential hypertension: the PROCAGENE study. Prospective cardiac gene. J Am Coll Cardiol 2001; 37(6): 1536-1542.

47. Buraczynska M, Pijanowski Z, Spasiewicz D, Nowicka T, Sodolski T, Widomska - Czekajska T, Ksiazek A. Renin-angiotensin system gene polymorphisms: assessment of the risk of coronary heart disease. Kardiol Pol 2003; 58(1): 1-9.

48. Sekuri C, Cam FS, Ercan E, Tengiz I, Sagcan A, Eser E, Berdeli A, Akin M. Renin-angiotensin system gene polymorphisms and premature coronary heart disease. J Renin Angiotensin Aldosterone Syst 2005; 6(1): 38-42.

49. Gardemann A, Lohre J, Cayci S, Katz N, Tillmanns H, Haberbosch W. The T allele of the missense Glu(298)Asp endothelial nitric oxide synthase gene polymorphism is associated with coronary heart disease in younger individuals with high atherosclerotic risk profile. Atherosclerosis 2002; 160(1): 167-175.

50. Rossi GP, Cesari M, Zanchetta M, Colonna S, Maiolino G, Pedon L, Cavallin M, Maiolino P, Pessina AC. The T-786C endothelial nitric oxide synthase genotype is a novel risk factor for coronary artery disease in Caucasian patients of the GENICA study. J Am Coll Cardiol 2003; 41(6): 930-937.

51. Schneider MP, Erdmann J, Delles C, Fleck E, Regitz-Zagrosek V, Schmieder RE. Functional gene testing of the Glu298Asp polymorphism of the endothelial NO synthase. J Hypertens 2000; 18(12): 1767-1773. 